University for Business and Technology in Kosovo

UBT Knowledge Center

UBT International Conference

2017 UBT International Conference

Oct 28th, 9:00 AM - 10:30 AM

\title{
Poverty and income inequality in the Republic of Macedonia
}

\author{
Remzije Rakipi \\ South East European University in Tetovo, r.rakipi@seeu.edu.mk \\ Shenaj Hadzimustafa \\ South East European University in Tetovo, s.daut@seeu.edu.mk
}

Follow this and additional works at: https://knowledgecenter.ubt-uni.net/conference

Part of the Business Commons

\section{Recommended Citation \\ Rakipi, Remzije and Hadzimustafa, Shenaj, "Poverty and income inequality in the Republic of Macedonia" (2017). UBT International Conference. 243. \\ https://knowledgecenter.ubt-uni.net/conference/2017/all-events/243 \\ This Event is brought to you for free and open access by the Publication and Journals at UBT Knowledge Center. It has been accepted for inclusion in UBT International Conference by an authorized administrator of UBT Knowledge Center. For more information, please contact knowledge.center@ubt-uni.net.}




\title{
Poverty and income inequality in the Republic of Macedonia
}

\author{
Remzije Rakipi ${ }^{1}$, Shenaj Hadzimustafa ${ }^{1}$ \\ ${ }^{1}$ Faculty of Business and Economics, South East European University in Tetovo, \\ r.rakipi@seeu.edu.mk, s.daut@seeu.edu.mk
}

\begin{abstract}
Past Governments in the R. Macedonia have failed to substantially boost economic growth and create new jobs. As such, the country remains challenged by an alarmingly high poverty and inequality in income distribution. Using official data from the State Statistical Office, it is the intention of this study to examine trends in poverty and income inequality in the R. Macedonia for the period 2010-2015.

The at-risk-of-poverty rate in the R. Macedonia has decreased 5.8 p.p. in the study period reaching $21.5 \%$ in 2015. The most vulnerable groups in this context are multi-member households and the unemployed when observing poverty by economic activity. Observing inequality in the income distribution in R. Macedonia, the study shows a positive trend, but still at an alarmingly high level. The Gini coefficient has decreased by 7.1 p.p. in the study period registering a coefficient of $33.7 \%$ in 2015 .
\end{abstract}

Key words: poverty, income inequality, Gini coefficient

\section{. Introduction}

Poverty and income inequality are concepts vastly studied and discussed in both academic and policymaking contexts. Both concepts present a challenge to Governments all around the world, but are more visible and manifest in some societies than others. The R. Macedonia represents one of the societies where poverty and income inequality is highly visible and manifested.

Low economic growth and slow job creation is and has been a serious problems for R. of Macedonia since its independence in 1991, and thus constantly struggling with high levels of poverty and income inequality. The Government has over the past decades not been silent towards these challenges and responded with several reforms and interventions to improve the socio-economic environment in the country in hope of eradicating poverty and income inequality to more acceptable levels. However, the reforms and interventions have failed to meet the desired long-term outcomes for increased welfare and well-being. Consequently, the country remains challenged by a high level of poverty and inequality in the distribution of income.

In addition to being signatory to a wide number of international conventions in the area of human rights and elimination of discrimination policies and its dedication to achievement of the EU integration priorities, the R. Macedonia has also expressed commitment to achievement of the UN Millennium Declaration in 2000. The Millennium Declaration, which was translated into a roadmap setting out eight time-bound and measurable goals to be reached by 2015 , otherwise known as the Millennium Development Goals (MDGs), explicitly calls for the commitment to reduce the proportion of the population living below the poverty line to $9.5 \%$ by 2015 .

In this context, it is aim of this study to examine developments in poverty and inequalities in distribution of incomes in the R. of Macedonia. This not only in relation to the achievement of the Milinium Development Goal, but also generally to understand the development in this area. 


\section{Litterature Review}

According to the State Statistical Office of the R. Macedonia, poverty is refers to persons, families, and groups of persons whose resources (material, cultural and social) are so limited that it excludes them from the minimum acceptable way of life in society. As such, the basis for poverty calculations is income, and the poverty threshold used in this case to define the adequate minimum is $60 \%$ of the median equivalent income. Wheras income inequality refers to the distribution of income in society. The latter is thus a broader concept than poverty in that it is defined over the entire population, and does not only focus on the poor. Income inequality is measured using Gini Coefficient and the S80/S20 indicator. The latter shows the ratio of total income received by the $20 \%$ of the population with the highest income to that received by the $20 \%$ of the population with the lowest income. Thus, the larger this relationship is, the greater the inequality is. The Gini coefficient, on the other hand, is a statistical measure that takes into account the overall income distribution in the country, which measures inequality in the distribution of income and wealth. If there were to be perfect equality, meanining that everyone in the society has the same income, then the coefficient would be $0(0 \%)$. If all national income were in the hands of one person, the coefficient would be $1(100 \%)$. Hence, the greater the Gini coefficient is, the greater is the income inequality the country. According to Petrevska and Uzunov (2015), the extreme values 0 and 1 are only theoretical cases and in practice the value of the Gini index ranges from about 0.25 to 0.7 .

The reason for observing poverty together with income distribution (income inequality) is that the distribution of income is an important determinant of poverty reduction (Nikolov et al. 2013). In the context of R.Macedonia, Nikolov et al. (2013) emphasizes that the gap between the citizens in the Republic of Macedonia is growing, where the proportion of the poorest $20 \%$ of the population is receiving decreases (below 5\%), while the proportion of the income received by the richest $20 \%$ of the population increases (over 50\%). According to the same author, this situation appears as a result of the failed long-term budgetary policy and the lack of a clear vision of the structure and distribution of wealth in society. On the other hand, Micajkova (2014) states that the main reason for the inequality in the R. Macedonia is the high level of unemployment. Even though the Government of the R. Macedonia in its policies has included several measures to reduce inequality, Micajkova (2014) believes that the introduction of a progressive personal income tax is an additional measure that should be taken into account in the future. This shows that social policies in the R. Macedonia failed to reduce the negative intensity of the social fragmentation of the country. That negative social fragmentation is evident in the R.Macedonia is supported also by Bexheti (2014), who refers to the continuing "melting" of the middle class more towards impoverishment rather than enrichment. According to the study by Bexheti (2014) $38.44 \%$ of the population in R.Macedonia belong to the middle class, $42.82 \%$ to the poor class and $18.74 \%$ to the rich class.

According Bexheti (2015), one of the factors that influence inequality in a country is the tax system arguing that if the poor in a given tax system continuee to be poor, it implies that total revenues are allocated to only a small part of the population. In this respect Bexheti (2015) concurs with Micajkova (2014) that a progressive tax system would contribute to a more equal distribution of income in the country and and reduce poverty.

\section{Methodology}

A valuable source for capturing events in poverty and inequalities is the Survey on Income and Living Conditions executed annually by the State Statistical Office of the R. Macedonia. Hence, 
for the sake of this study, official data published from this institution for the period 2010-2015 forms the primary basis for our observations and conclusions. The relative short period included in the study rests on the fact that the R. Macedonia started measuring poverty since 1996 using a national framework, and that it only in 2010 adopted the European framework for measuring poverty. Making it thus difficult to compare developments over a longer study period and especially in respect to the achievement of the Millennium Development Goal for poverty reduction.

\section{Data Analysis}

According to data for the period 2010-2015 presented in Table 1, the poverty level in the R. Macedonia has decreased in the study period with 5.8 p.p. reaching $21.5 \%$ in 2015 . Seeing this percentage in absolute terms using the current population of approximately two million people in the R. Macedonia, the figures shows that approximately 430.000 people in the country live in poverty. The situation is much more alarming if we observe the at-risk-of-poverty rate before social transfers and before pensions, which indicates that double the amount of people mentioned above live below the poverty threshold.

The at-risk-of-poverty rate clearly states that the R. Macedonia is far from meeting the Millennium Goal for poverty reduction with substantial efforts required by the Governments side to reduce this level to $9.5 \%$ as committed.

Table 2. At-risk-of-poverty rate in the Republic of Macedonia, in percentage, 2010-2015

\begin{tabular}{|l|l|l|l|l|l|l|}
\hline Indicators / Year & 2010 & 2011 & 2012 & 2013 & 2014 & 2015 \\
\hline $\begin{array}{l}\text { At-risk-of-poverty rate, \% of } \\
\text { population }\end{array}$ & 27.3 & 26.8 & 26.2 & 24.2 & 22.1 & 21.5 \\
\hline $\begin{array}{l}\text { At-risk-of-poverty rate before social } \\
\text { transfers and before pensions, \% of } \\
\text { population }\end{array}$ & 42.8 & 43.9 & 42.6 & 41.0 & 41.7 & 40.5 \\
\hline $\begin{array}{l}\text { At-risk-of-poverty rate by most } \\
\text { frequent activity status-Employed }\end{array}$ & 9.9 & 10.2 & 11.1 & 11.1 & 9.8 & 8.9 \\
\hline $\begin{array}{l}\text { At-risk-of-poverty rate by most } \\
\text { frequent activity status-Unemployed }\end{array}$ & 50.6 & 48.7 & 46.5 & 43.7 & 40.4 & 39.7 \\
\hline $\begin{array}{l}\text { At-risk-of-poverty rate by household } \\
\text { type-Households of two adults with } \\
\text { two dependent children }\end{array}$ & 22.7 & 21.4 & 24.3 & 24.8 & 25.0 & 22.9 \\
\hline $\begin{array}{l}\text { At-risk-of-poverty rate by household } \\
\text { type-Households of two adults with } \\
\text { three or more dependent children }\end{array}$ & 36.5 & 49.6 & 53.9 & 49.9 & 51.1 & 52.2 \\
\hline
\end{tabular}

Source: State Statistical Office (Laeken indicators of poverty, 2010-2015)

Observing data based on employment and unemployment, the study clearly suggests that unemployed people are at much higher risk of poverty with $39.7 \%$ of unemployed living in poverty in 2015 in contrast to employed in the same year (8.9\%). The trend for the at-risk-ofpoverty rate for the unemployed shows a substantial decrease in the study period by 10.9 p.p. but remains at very high level registering $39.7 \%$ in 2015 . While the at-risk-of-poverty rate for the employed has registered a marginal drop in study period by 1.0 p.p. with a marginal increase registered in both 2011 and 2012. 
Observing Table 1, clearly the most vulnerable group towards poverty in the R. Macedonia includes households of two adults with three or more dependent children. However, more alarming is that this category has registered a 15.7 p.p. increase in the study period reaching $52.2 \%$ in 2015. Meaning that every second household of two adults with three or more dependent children are living in poverty. As observed, this category is much more vulnerable to poverty in contrast to households of two adults with two dependent children, which registered an at-risk-ofpoverty rate of $22.9 \%$ in 2015 and a marginal increase of $0.2 \%$ over the entire study period. Noteworthy is that for these two category, the Government allocates funds for poverty alleviation. One of these measures is the Social Cash Assistance (SCA). However, this measure perceived as ineffective in contributing to the reduction of poverty due to the low amount provided and to the fact that the amount only increases by a 0.37 coefficient for any additional member of the family and this only up to five members. Consequently, households with more than five members remain at great risk of poverty. According to Nikolov et al. (2013), another concern in the R. Macedonia is the growth of households living in poverty where the head of the family has completed higher education. Thus, suggesting that there is no positive link between education and poverty in the Republic of Macedonia. Nikolov et al. (2013) further concludes that the high level of poverty in the country can also be attributed to increasing participation of citizens in private financing of public services such as education and health. If these costs could be excluded from the private consumption of citizens, the level of poverty in the country would be reduced.

Table 3. Inequality of income distribution in the Republic of Macedonia, in percentage, 2010-

\begin{tabular}{|l|l|l|l|l|l|l|}
\hline Indicators / Year & 2010 & 2011 & 2012 & 2013 & 2014 & 2015 \\
\hline $\begin{array}{l}\text { Inequality of income distribution, } \\
\text { Gini coefficient }\end{array}$ & 40.8 & 38.5 & 38.8 & 37.0 & 35.2 & 33.7 \\
\hline $\begin{array}{l}\text { Inequality of income distribution, } \\
\text { S80/S20 }\end{array}$ & 11.3 & $\mathbf{1 0 . 6}$ & $\mathbf{1 0 . 2}$ & $\mathbf{8 . 4}$ & $\mathbf{7 . 2}$ & $\mathbf{6 . 6}$ \\
\hline
\end{tabular}

Source: State Statistical Office (Laeken indicators of poverty, 2010-2015)

As observed in Table 2, both indicators for inequality of income distribution, Gini coefficient and S80/S20 indicator, show a decreasing trend throughout the study period. The Gini coefficient has decreased by 7.1 p.p. from $40.8 \%$ in 2010 to $33.7 \%$ in 2015 . While the S80/S20 indicator has decreased from $11.3 \%$ in 2010 to $6.6 \%$ in 2015 . However, despite the notable decrease in both the Gini coffcient and the S80/S20 indicator, the data shows that there is still a great income inequality in the R. Macedonia. The highest rate of income inequality was observed in 2010 $(40.8 \%)$, which corresponds to the highest rate of poverty $(27.3 \%)$ in the same year; showing that the growth of income inequality affects poverty in the country. The same is confirmed also by the Ministry of Finance (2017), which states that the R. Macedonia has a record-high income inequality in Europe, where the top $1 \%$ share of income in the country hold $14 \%$ of the total income while one percent have a monthly income of over 1.523 euros, while $50 \%$ are below 212 euros per month.

\section{Concluding Remarks}

The study shows progress in reducing poverty and income inequality in the R. Macedonia. However, the conclusion is that both remain at an alarming level.

Poverty and inequality in income distribution are clearly complex challenges that cannot be easily and quickly reduced and/or eradicated. In addition to effective support programs for the poor and for those at risk of becoming poor, the government needs to seriously address socio-economic factors contributing to poverty reduction and undertake educated reforms in both taxation and 
social policy to ensure effective and long-lasting impacts on poverty and income inequality. The Government should especially endeavour to reduce unemployment amongst more vulnerable groups such as youth, females, and certain ethnic groups and households comprising of large families.

\section{References}

1. Bexheti, A.: The middle class in the Republic of Macedonia. Macedonian Academy of Sciences and Arts. Contributions. Section of social sciences, XLV 1. Skopje (2014)

2. Micajkova, V.: Income disparity increase in the countries in the world presented trough the Gini index. Political thought. Functioning Market Economy and Social (in) Equality. Year 12, No 47, September Skopje (2014) 63

3. Ministry of Finance: Income Inequality in Macedonia, available at http://www.finance.gov.mk/en/inequality (2017)

4. Nikolov, M., Risteski, H. and Trnovski, B.: Political consensus for the economic future of Republic of Macedonia. Center for Economic Analyses-CEA (2013) 30

5. Petrevska, B. and Uzunov, V.: Social inequality in the Republic of Macedonia. ERAZ konferencija. Održivi ekonomski i razvoj-savremeni i multidisciplinarni pristupi (2015) 136-143

6. State Statistical Office: Survey on Income and Living Conditions 2010-2015. Avaible at:

7. http://www.stat.gov.mk/PublikaciiPoOblast_en.aspx?id=68\&rbrObl=13 